\title{
User Effects on Chamber Nitrous Oxide Emissions From Oxisol Soils in No-Tillage Maize Fertirrigated With Anaerobically Digested Swine Manure
}

\author{
Ivan Bergier ${ }^{1}$, Rubia Rech ${ }^{1}$, Hernandes Monteiro ${ }^{1} \&$ Eduardo Soriano ${ }^{2}$ \\ ${ }^{1}$ Laboratory of Biomass Conversion, Embrapa Pantanal, Corumbá, Brazil \\ ${ }^{2}$ Coordination of Energy's Office of Technology Development and Innovation, Brazilian Ministry of Science, \\ Technology and Innovation, Brasília-DF, Brazil \\ Correspondence: Ivan Bergier, Laboratory of Biomass Conversion, Embrapa Pantanal, Corumbá, Mato Grosso \\ do Sul P. O. 109, Brazil. Tel: 55-67-3234-5825. E-mail: ivan.bergier@embrapa.br
}

Received: June 15, 2013 Accepted: July 17, 2013 Online Published: July 29, 2013

doi:10.5539/enrr.v3n4p1 URL: http://dx.doi.org/10.5539/enrr.v3n4p1

\begin{abstract}
Closed static chambers are frequently adopted for estimating gas fluxes across environmental interfaces. In this study we assessed the effects of three gas sampling rates and two methods of chamber placement in fertirrigated soils for estimating nitrous oxide $\left(\mathrm{N}_{2} \mathrm{O}\right)$ emissions, using chambers with similar design and on-site gas chromatography. The soils under analysis were fertirrigated with (liquid) digested swine manure at three different doses. The results indicate that $\mathrm{N}_{2} \mathrm{O}$ flux estimates are firmly determined by the chosen sampling rate, chamber placement, chamber design, and the emission magnitude itself. $\mathrm{N}_{2} \mathrm{O}$ fluxes were best estimated by faster sampling rates while gently placing the chamber at the soil surface due to conspicuous $\mathrm{N}_{2} \mathrm{O}$ emissions and relatively small chamber volume. A generalized chamber accumulation model developed by normalizing the dataset was used to illustrate effects on expected "low unforced-chamber", "high unforced-chamber" and "high forced-chamber" fluxes. We concluded that it is possible to adopt simple design and low-disturbing chambers with sufficient volume, height, and surface area for determining gaseous emissions across soil-air interfaces. Nevertheless, critical on-site gas sampling rate adjustment (by gas chromatography or other as precise real-time measuring device) is critical to avoid estimation inaccuracies in emission estimates.
\end{abstract}

Keywords: agroecosystems, greenhouse gases, climate change, agroforestry-livestock integration, sustainable production

\section{Introduction}

Nitrous oxide $\left(\mathrm{N}_{2} \mathrm{O}\right)$ is a powerful greenhouse gas with an assigned Global Warming Potential three decades greater (298) than that of carbon dioxide, in a 100-year time horizon (Forster et al., 2007). The atmospheric molar fraction of $\mathrm{N}_{2} \mathrm{O}$ has been considerably increasing since the last century, and anthropogenic contributions are associated particularly to manure and mineral $\mathrm{N}$ fertilizer application to soils for food production (Davidson, 2009). As a result, there are growing national incentives for the development of $\mathrm{N}_{2} \mathrm{O}$ emission mitigation strategies, which include increasing efficiency of $\mathrm{N}$ use in crop production (Burney, J. A., Davisc, S. J., \& Lobella, D. B., 2010) and improved manure management in livestock systems (Oenema, 2005).

A practical strategy from the point of view of sustainability is the integration of livestock systems to agriculture in the same landscape, converting environmental externalities (manure) into renewable energy, which is useful to improve nutrient cycling and economic profitability for agroecosystems. From this perspective, the most promising approach is the anaerobic biodigestion that provides biogas and liquid fertilizer rich in macro and micronutrients (Massé, D. I., Talbot, G., \& Gilbert Y., 2003; Bergier et al., 2012). For instance, digested swine manure applied to agroecosystem may emit less $\mathrm{N}_{2} \mathrm{O}$ per unit $\mathrm{N}$ applied, because the recalcitrant organic carbon in the digested manure can reduce the denitrification of $\mathrm{NO}_{3}$ in soils (Velthof, G. L., Kuikman, P. J., \& Oenema, O., 2003; Chantigny et al., 2007). However, the amount of $\mathrm{N}$ applied to soils shall be carefully controlled in coherence with soil nutritional status and crop demands to avoid $\mathrm{N}$ atmospheric emissions, $\mathrm{N}$ runoff to surface waters, and $\mathrm{N}$ leaches to groundwater (Sutton et al., 2011).

For successfully accomplishing best practices in the integration of agriculture to livestock systems, a 
well-designed monitoring approach must be implemented for modeling, hence simulating scenarios to achieve "best" configuration system performance. We have initiated a long term monitoring program for evaluating the application of digested swine manure over an integrated agroecosystem including forestry (eucalyptus), no-tilling crop rotation, and cultivated pasture. By improving soil fertilization it is expected to increase the productivity of the agroecosystem whilst mitigating nutrient losses to atmospheric, terrestrial, and aquatic environments. In specific, the $\mathrm{N}_{2} \mathrm{O}$ monitoring is essential to regulate or develop strategies to accomplish lower greenhouse gas emissions from the swine-agroecosystem integration.

Although controversial, a low-cost method for estimating fluxes is the acquisition of gas samples from an enclosed volume (chamber) attached to the soil-air interface (Hutchinson, G. L., \& Livingston, G. P., 2001). In crops with artificial $\mathrm{N}$ inputs, chamber and micrometeorological flux estimations (Laville, P., Jambert, C., Cellier, P., \& Delmas, R., 1999) are supposed to capture the connection on $\mathrm{N}_{2} \mathrm{O}$ fluxes with the soil water filled pore space and denitrification rate (Singurindy et al., 2009), though it seems that micrometeorological technique is inadequate for estimating low emissions while chambers can underestimate above average fluxes (Wang et al., 2013). Chamber artifacts and biases can cause serious errors in gas exchange measurements, but these sources of error have been well described in the literature and can be minimized or avoided (Davidson et al., 2002). The difficulties for estimating accurate gaseous emissions are related to i) positive (negative) inner pressure by chamber compression (gas sampling) (Hutchinson et al., 2001; Davidson et al., 2002; Christiansen et al., 2011), ii) depth of chamber insertion into sandy or clay soils (Hutchinson et al., 2001), iii) manual sampling with no headspace mixing (Christiansen et al., 2011), and iv) deformation (extinction) of the $\mathrm{N}_{2} \mathrm{O}$ gradient into the chamber (Rochette et al., 2011). Contributing to filling these gaps, we show that, for a constant chamber volume and at relatively high $\mathrm{N}_{2} \mathrm{O}$ emission rates, forced placement of the chamber, large sampling rate and general linear regression assumptions may provide underestimated fluxes. We further derive a logistic generalized model adjusted to a normalized dataset to improve the understanding of user effects on chamber deployments, allowing minimization of inaccuracies in $\mathrm{N}_{2} \mathrm{O}$ flux estimates through statistical regression models.

\section{Method}

\subsection{Local Information}

Embrapa and an agribusiness cooperative (Cooasgo) has joined efforts to create a demonstration unit for implementing the first long-term monitoring swine-agroecosystem integration in Brazil. Several parameters will be obtained over this swine-agroecosystem experiment. The study area is located in São Gabriel do Oeste, Mato Grosso do Sul estate, in the Upper Taquari River Basin (19 $\left.17^{\prime} 26.58^{\prime \prime S}, 54^{\circ} 36^{\prime} 10.33^{\prime \prime W}\right)$, adjacent to the Pantanal wetland and over the Guarani Aquifer.

The land-use changes of the Brazilian Cerrado with Embrapa technology have been promoting expressive increases in the crop productivity over the last 30 years. On the other hand, the Pantanal is one of the largest wetlands of the world with unique biodiversity. The vast Guarani Aquifer has singular water drinkability and stores as much water as the whole Amazon basin. Therefore, the technologies of biodigestion and biogas-to-energy (Rieger, 2006) have been essentially advanced in the region to cope with the disposal of large quantities of swine manure, reducing impacts over Cerrado soils, Pantanal rivers, and Guarani groundwater. In addition, the recent integration of intensive swine with renewable energy and grain/beef/wood production has been viable especially due to significant revenue to both small and medium farmers in cooperatives.

\subsection{Swine-Agroecosystem Integration}

Figure 1 illustrates the sustainable farm approach integrating intensive swine livestock to agriculture with the aim to enhance productivity and revenue, while mitigating environmental pollution. The systemic approach involves the efficient use of an anaerobic digester for continuously produce biogas and liquid digested manure for fertirrigation (irrigation of large areas with the liquid digested manure). Practically the entire system following the swine feedlot is operated by renewable energy and fertilizers, minimizing the dependence on fossil fuel resources (diesel oil and Haber-Bosch reactive N). The flow of liquid manure fertilizer is indicated by green lines and the biogas flow is represented by blue lines. 

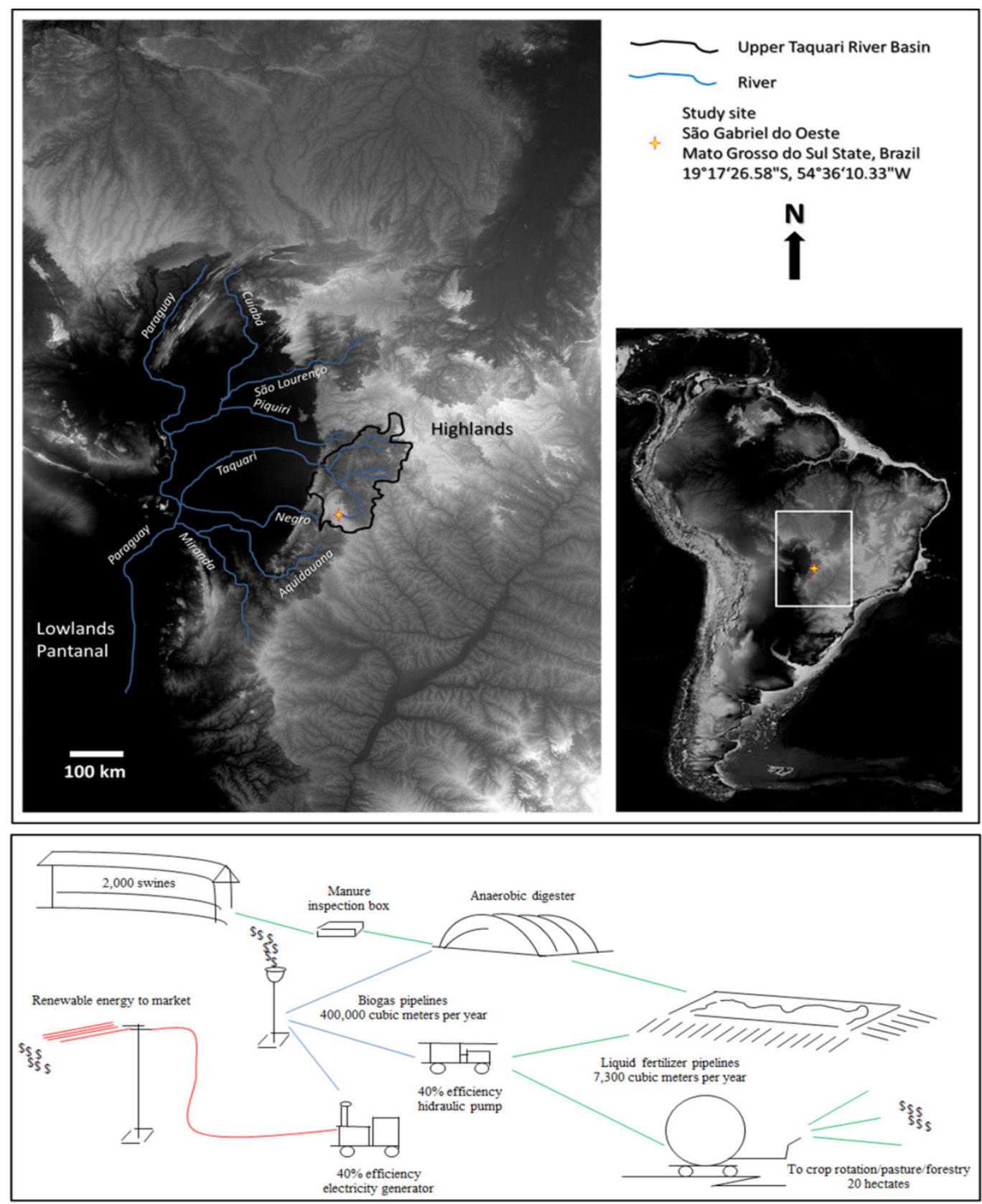

Figure 1. Location of the study site (box above, digital elevation data obtained in http://srtm.csi.cgiar.org/SELECTION/inputCoord.asp) and schematic description of the integrated swine-agroecosystem monitored for air, soil and water qualities (box below)

Environmental pollution converted to revenue such as CER (Certified Emission Reduction), renewable energy (red lines) and integrated crop is indicated by $\$$ clouds. Under local climate conditions and standardized feed intake, three cycles per year of two thousand swine produces roughly 400 thousand cubic meters of biogas with 50 to $60 \%$ as $\mathrm{CH}_{4}$ by volume. A fraction of the biogas has been burnt for CER while the remainder is easily directed to produce about $50 \mathrm{~kW}$ of continuous power in local diesel-to-biogas adapted generator (Rieger, 2006) with an energy efficiency of $\sim 40 \%{ }^{2}$. The remaining biogas eventually feeds a diesel-to-biogas adapted hydraulic pump $^{2}$ to draw liquid fertilizer from the lagoon to a fertirrigation system (450-m dragging hard hose reel with a gun cart traveler) for dispersing it in a "rainy" mode over stripes of 60 meters width $(2.7$ hectares per line of dragging). The annual 7.3 thousand cubic meters of liquid fertilizer about 7.4 ton of organic $\mathrm{N}^{-\mathrm{NH}_{4}}$ per year can be applied, for instance, to 20 hectares of integrated forestry/grain-pasture-rotation over two crop seasons, providing about $180 \mathrm{~kg} \mathrm{~N}-\mathrm{NH}_{4} \cdot$ hectare ${ }^{-1} \cdot \mathrm{crop}^{-1}$ in addition to other important macro $(\mathrm{P}, \mathrm{K})$ and micronutrients ${ }^{2}$. 


\subsection{Sampling Procedures}

We have delimited three fertirrigated stripes planted with maize in 3 dosage treatment plots of $20 \times 20 \mathrm{~m}$ over no-tillage clay (oxisol) soils. The flux dataset was obtained using three static chambers at each plot operated by three different users in the same time of $10^{\text {th }}$ May, 2012. Information on the sampling scheme and the amount of $\mathrm{N}$ applied (mostly as reduced $\mathrm{N}-\mathrm{NH}_{4}$ ) is presented in Table 1. The "rainy" fertirrigation at each plot was measured by fitting at the soil surface three $7.5-\mathrm{cm}$ diameter cup collectors made in PVC. The captured liquid volume for each cup was determined after a few hours of the fertirrigation procedure.

Table 1. Description of the chamber flux measurements across the soil-air interface of maize fertirrigated plots

\begin{tabular}{lccc}
\hline & Plot 1 & Plot 2 & Plot 3 \\
\hline Dosage of liquid fertilizer applied at the top soil level $\left(\mathrm{L} \cdot \mathrm{m}^{-2}\right)$ & $1.77 \pm 0.06$ & $2.38 \pm 0.11$ & $5.79 \pm 0.22$ \\
Dosage of $\mathrm{N}-\mathrm{NH}_{4}$ applied at the top soil level $\left(\mathrm{g} . \mathrm{m}^{-2}\right)^{\mathrm{a}}$ & $1.79 \pm 0.07$ & $2.41 \pm 0.11$ & $5.86 \pm 0.23$ \\
Number of chambers & 3 & 3 & 3 \\
Number of users & 3 & 3 & 3 \\
\hline & User 1 & User 2 & User 3 \\
\cline { 2 - 4 } Gas sampling rate $\Delta \mathrm{t}$ (minutes) with 60-mL plastic syringes & 2 & 4 & 6 \\
Method of chamber attachment to the soil-air interface & Unforced & Forced & Forced
\end{tabular}

${ }^{a}$ Obtained by subtracting from $2.8 \mathrm{~g} \mathrm{~N}-\mathrm{NH}_{4} \cdot \mathrm{L}^{-1} 54 \%$ losses as volatilization from lagoon and fertirrigation procedure.

\subsection{Experimental Manipulations or Interventions}

Gas flux measurements were made 1-2 weeks after fertirrigation depending on the measured plot. The three chambers were identically constructed in PVC $(31 \mathrm{~cm}$ diameter $\times 15 \mathrm{~cm}$ height $)$ with a sharp cutting edge to allow rotating hand-forcing attachment of the chamber into the soil surface. Such configuration was based on the assumption that the use of a "semi-permanent collar" minimizes soil disturbances, especially in fertirrigated soils Collars can result in biased measurements when they affect soil moisture by preventing run-off, affect soil temperature by shading the soil, and affect gas exchange by formation of shrinkage cracks at the collar-soil interface (Rochette et al., 2011). It was decided not to remove the plant residue layer covering the top soil, left in the ground in the previous soybean crop.

Only two users $(2 \& 3)$ were allowed to rotate and force the chamber at about $1 \mathrm{~cm}$ into the soil. User number 1 gently fitted (unforced rotation) the chamber to the soil surface (penetration $<<1 \mathrm{~cm}$ ). At the middle top of the chamber, in a small aperture, it was bonded a syringe needle port without the metal needle (the metal needle was broken and removed to avoid handling injuries in the field). The 5-mm inner diameter port for the gas sampling syringe was nearly aligned to the external top chamber surface while the remaining plastic body of the broken syringe port was inserted into the chamber. A gas sample with a $60-\mathrm{mL}$ plastic syringe was acquired only after a single slow flushing procedure. Between two consecutive gas samplings, the aperture was left open for a few moments (less than 15 seconds). In relation to the external $5-\mathrm{mm}$ diameter syringe port, the small $<1 \mathrm{~mm}$ diameter of the broken needle hole allowed inner chamber pressure equilibration after sampling with minimal influence of the well-known wind-induced Venturi effect on fully vented chambers (Conen \& Smith, 1998; Bain et al., 2005). The sampling rate was different for each user (Table 1) though the number of gas samples for the deployments were fixed at $n=4$ because the uncertainty of an eventual non-linear component of the concentration versus time curve cannot be assessed with $\mathrm{n}<4$ sampling points (Rochette et al., 2011).

$\mathrm{N}_{2} \mathrm{O}$ quantification of gas samples stored in syringes was immediately carried out with nitrogen 5.0 carrier/make-up gas line coupled to a SRI GC8610 gas chromatography system equipped with a ${ }^{63} \mathrm{Ni}$ Electron Capture Detector ECD. The GC/ECD system has an automated 1-ml solenoid sample loop to improve the analytical certainty. Each $60-\mathrm{ml}$ gas sample syringe was directly measured in duplicates $(30 \mathrm{ml}$ each time) to assess analytical errors (measured as $2 \%$ on average) and we used the obtained mean value in data analysis and modeling. Chromatographic peaks were integrated individually and a certified gas standard (White Martins) containing $0.316 \mathrm{~mol} \cdot \mathrm{mol}^{-1}$ of $\mathrm{N}_{2} \mathrm{O}$ was used for calibration.

$\mathrm{N}_{2} \mathrm{O}$ fluxes (F) from fertirrigated plots measured by different users were calculated by linear regressions between 
the changes of the molar fraction of the gas inside the chamber with time $(\mathrm{C} / \mathrm{t})$. These values were then associated to the molar mass of $\mathrm{N}_{2} \mathrm{O}(\mathrm{M})$, chamber surface area $(\mathrm{A})$, volume $(\mathrm{V})$, laboratory temperature $(\mathrm{T})$ and pressure $(\mathrm{P})$ by $\mathrm{F}=(\mathrm{C} / \mathrm{t}) \times \mathrm{M} \times \mathrm{PV} /(\mathrm{ART})$, where $\mathrm{R}$ is the ideal gas constant.

\section{Results and Discussion}

\subsection{Field Data}

Figure 2 shows the time evolution of the $\mathrm{N}_{2} \mathrm{O}$ molar fraction measured in the chamber deploy experiments. We clearly note from Figure 2 that the more $\mathrm{N}_{-} \mathrm{NH}_{4}$ offered to the soil system (Table 1) the higher is the corresponding $\mathrm{N}_{2} \mathrm{O}$ molar fractions inside the chambers (Figure 2A).
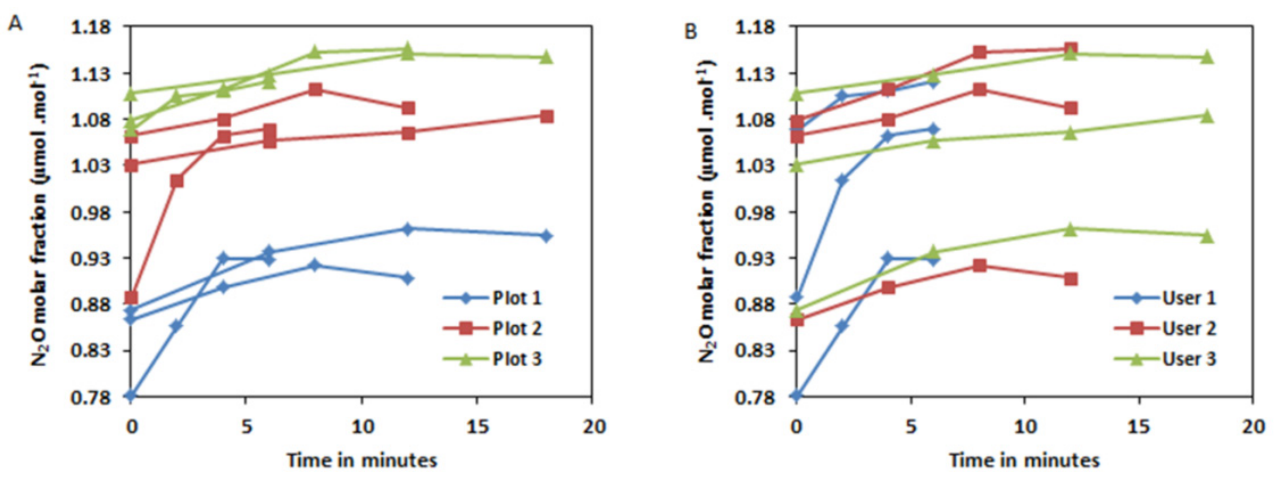

Figure 2. Time evolution of the $\mathrm{N}_{2} \mathrm{O}$ molar fraction for nine static chamber deployments in three fertirrigated plots (A), operated by three different users (B). Refer to Table 1 for additional information on plot fertirrigation dosages and user operations)

Conversely, see in Figure 2B that depending on the chosen technique in the field sampling (Users) the linear gas flux estimates are fully contrasting with the previous deduction (see also Table 2). User 1 data obtained $\mathrm{N}_{2} \mathrm{O}$ ranges (the difference between maximum and minimum molar fraction values) of 0.148 and $0.182 \mathrm{~mol} \cdot \mathrm{mol}^{-1}$ in Plots 1 and 2, respectively. The same ranges obtained by User 2 are respectively 0.058 and $0.051 \mathrm{~mol} \cdot \mathrm{mol}^{-1}$ and for User 3 are respectively 0.088 and $0.053 \mathrm{~mol} \cdot \mathrm{mol}^{-1}$. In other words, the time-derived gradient of $\mathrm{N}_{2} \mathrm{O}$ was reduced in 1.7 to 3.6 times by forcing the chambers in the soil surface at the start of the deployments. This artifact reflected in $\mathrm{N}_{2} \mathrm{O}$ flux underestimation by Users 2 and 3 by 6 - to 15 -fold, despite of the reasonable values of goodness-of-fit $\mathrm{R}^{2}$ (Table 2).

Table 2. $\mathrm{N}_{2} \mathrm{O}$ emissions as measured by usual linear regressions with acceptable goodness of fit $\mathrm{R}^{2}$

\begin{tabular}{|c|c|c|c|c|c|c|}
\hline & \multicolumn{2}{|l|}{ User 1} & \multicolumn{2}{|l|}{ User 2} & \multicolumn{2}{|l|}{ User 3} \\
\hline & Flux $\left(\mathrm{mg} \mathrm{N}_{2} \mathrm{O} \cdot \mathrm{m}^{-2} \cdot \mathrm{h}^{-1}\right)$ & $\mathrm{R}^{2}$ & Flux $\left(\mathrm{mg} \mathrm{N}_{2} \mathrm{O} \cdot \mathrm{m}^{-2} \cdot \mathrm{h}^{-1}\right)$ & $\mathrm{R}^{2}$ & Flux $\left(\mathrm{mg} \mathrm{N}_{2} \mathrm{O} \cdot \mathrm{m}^{-2} \cdot \mathrm{h}^{-1}\right)$ & $\mathrm{R}^{2}$ \\
\hline$\overline{\text { Plot } 1}$ & 0.392 & 0.887 & 0.060 & 0.660 & 0.068 & 0.738 \\
\hline Plot 2 & 0.453 & 0.831 & 0.047 & 0.558 & 0.042 & 0.971 \\
\hline Plot 3 & 0.122 & 0.846 & 0.104 & 0.920 & 0.036 & 0.848 \\
\hline
\end{tabular}

Besides, the gas sampling rate is an important choice to be considered, especially at high emission rates induced by considerable soil $\mathrm{N}$ inputs. In Figure $2 \mathrm{~A}$ it is possible to note for Plots 1 and 2 that the $\mathrm{N}_{2} \mathrm{O}$ molar fraction increases quasi-linearly up to an asymptotic turning point at $\sim 5$ minutes. This might be a response of the chamber to saturation due to the deformation of the $\mathrm{N}_{2} \mathrm{O}$ gradient downward (Rochette, 2011). Therefore, a chamber with the same surface area but with a greater height (up to a certain limit) would saturate at a deploy time $>5$ minutes and possibly at a higher molar fraction limit (due to greater headspace volume). The cause for not obtaining this behavior for Plot 3 by User 1 deployment can be assigned to very high $\mathrm{N}_{2} \mathrm{O}$ emission fluxes at this site, as the amount of $\mathrm{N}$ applied is 2.4 to 3.3 as much of that applied to Plots 2 and 1, respectively. If this assumption is correct, the chamber volume was not enough to capture the initial $\mathrm{N}_{2} \mathrm{O}$ molar fraction increases at 
Plot 3 (Figure 2A), that received a great amount of $\mathrm{N}$ (Table 1), even for $\mathrm{t}=2$ minutes (User 1, Figure 2B), hence the molar fraction asymptotic limit was quickly achieved.

\subsection{Modeling Approach}

In this section we introduce a generalized chamber accumulation model by normalizing the dataset obtained in the field. The normalization was achieved by dividing each measurement by the maximum value obtained for each chamber deployment. The model was conceived based on the results verified in Figure 2A, in which is naturally expected the presence of a quasi-asymptotic regime for long chamber deploy time or for high soil emission fluxes. The iterative logistic model can be written as $C(t+1)=C(t) e^{r[1-(C(t) / C \max )]}$ where $C$ is the normalized $\mathrm{N}_{2} \mathrm{O}$ molar fraction, $\mathrm{t}$ is the discrete time for $\mathrm{t}=1$ minute, $\mathrm{r}$ is the logistic growth rate, and Cmax is the asymptotic value (indeed the real partial gas pressure at this point is a function of both chamber design and flux magnitude). The superposition of the normalized data over the generalized chamber accumulation model $(\mathrm{r}=0.5$, $\mathrm{C}(\mathrm{t}=0)=0.83$, and $\mathrm{Cmax}=1)$ is shown is Figure 3 .

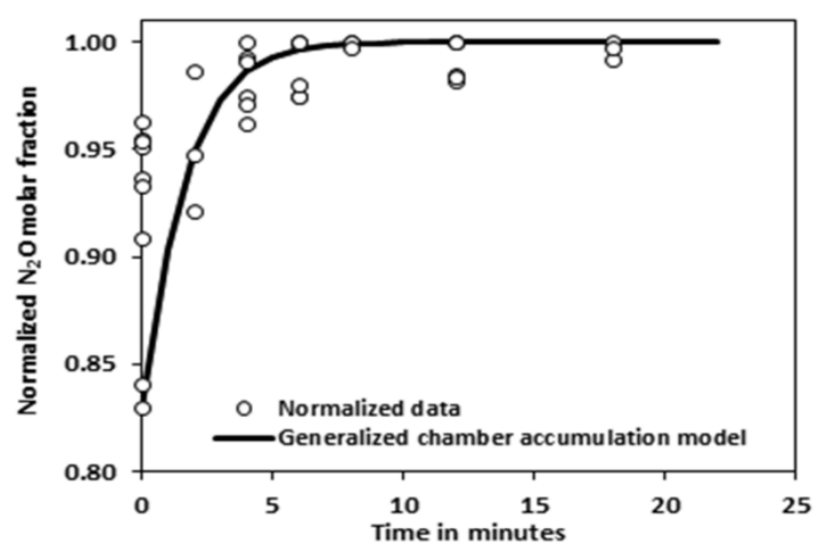

Figure 3. Generalized model overlaid to normalized chamber dataset for all plots/users

By this generalized model we can suitably assess different field $\left(\mathrm{N}_{2} \mathrm{O}\right.$ emission source) and user (sampling method) patterns for our chamber design. We initially verified unforced (gently attached to the soil) chamber behavior accordingly to $\mathrm{N}_{2} \mathrm{O}$ emission sources of low $\left(\mathrm{r}=0.04, \mathrm{C}(\mathrm{t}=0)=0.78 \mathrm{~mol} \cdot \mathrm{mol}^{-1}, \mathrm{C}_{\max }=0.95\right.$ $\left.\mathrm{mol} \cdot \mathrm{mol}^{-1}\right)$ and high $\left(\mathrm{r}=0.4, \mathrm{C}(\mathrm{t}=0)=0.78 \mathrm{~mol} \cdot \mathrm{mol}^{-1}, \mathrm{C}_{\max }=0.95 \mathrm{~mol} \cdot \mathrm{mol}^{-1}\right)$ magnitudes. Model outputs are shown in Figure 4A.

The "unforced high flux" model achieves the asymptotic behavior in about 5 minutes (Figure 4A), likewise to Plots 1 and 2 (Figure 2A). The "unforced low flux" model resembles a linear behavior up to 20 minutes (Figure $4 \mathrm{~A}$ ), though it is indeed a logistic model that reaches the asymptote far at $\mathrm{t} \sim 200$ minutes (not shown). In Figure $4 \mathrm{~B}$ we plotted the linear regression goodness-of-fit $\mathrm{R}^{2}$ for increasing sampling $\mathrm{n}$ from 4 to 20 with $t=1$ minute. For the "unforced low flux" model, a good linearity or acceptable goodness-of-fit is satisfied in the whole 20 -minute deploy time range, which is, however, rarely observed for the "unforced high flux" model (Figure 4B).

The estimation of the gas flux rate do not change significantly for the "unforced low flux" model by increasing sampling $\mathrm{n}$ from 4 to 20 with $\mathrm{t}=1$ minute. For the "unforced high flux" model the decreasing bias accentuates as a function of increasing n (Figure 4C). As a result, the higher the "likely emission flux", the greater should be the headspace volume of the chamber to decrease the asymptotic $C_{\max }$ value and to increase the asymptotic time as $\mathrm{t}_{\text {asymptote }}>>\mathrm{t}_{0}$. If chamber design is unchanged, minimal must be the sampling time $\mathrm{t}$, which will tightly depend on the internal pressure recovery time under successive short-time depressurizing sampling events (Christiansen et al., 2011) or on the accuracy and detection limit of a continuous $\mathrm{N}_{2} \mathrm{O}$ measuring system device. 

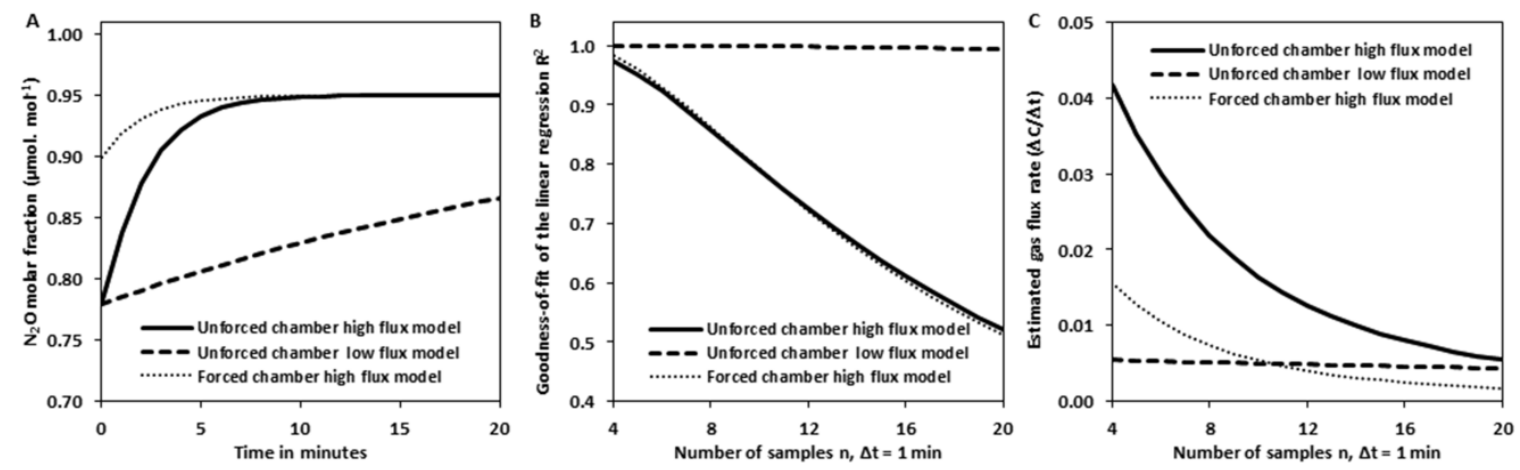

Figure 4. Comparison of low and high emissions fluxes for unforced chamber and a high flux forced chamber models (A), concerning the goodness-of-fit (B) for linearly estimated flux rates (C)

We used the same modeling approach to investigate the effect of forcing the chamber $(\mathrm{C}(\mathrm{t}=0)=0.90$ mol.mol $\left.{ }^{-1}\right)$ in the soil surface under high emission flux $\left(r=0.4, C_{\max }=0.95 \mathrm{~mol} \cdot \mathrm{mol}^{-1}\right)$ conditions (Figure 4A, dotted line). The decreasing bias is severely accentuated for the forced chamber in Figures 4B and 4C. Under chamber forcing imposed by user, a "likely emission flux" cannot be recovered from statistical regression procedures, even altering sampling time interval. Therefore, if the chamber is not gently attached to soil, also for chambers with associated pre-mounted collars, gas fluxes at the soil-air interface might be underestimated due to an abrupt increase in the $\mathrm{N}_{2} \mathrm{O}$ molar fraction at the beginning of the chamber deployment. By discarding the initial gas samples, gas flux estimates is still inaccurate, despite of an eventual improve in the linear goodness-of-fit, because the headspace $\mathrm{N}_{2} \mathrm{O}$ molar fraction has already achieved or is already close to the asymptotic chamber-flux-specific $\mathrm{C}_{\max }$ value. The forced chamber effect might be negligible only under sufficiently high chamber headspace volume or low gaseous source of emission that usually need enough deployment time to be accurately detectable (Davidson et al., 2002). Figure 5 summarizes main findings and premises discussed here.

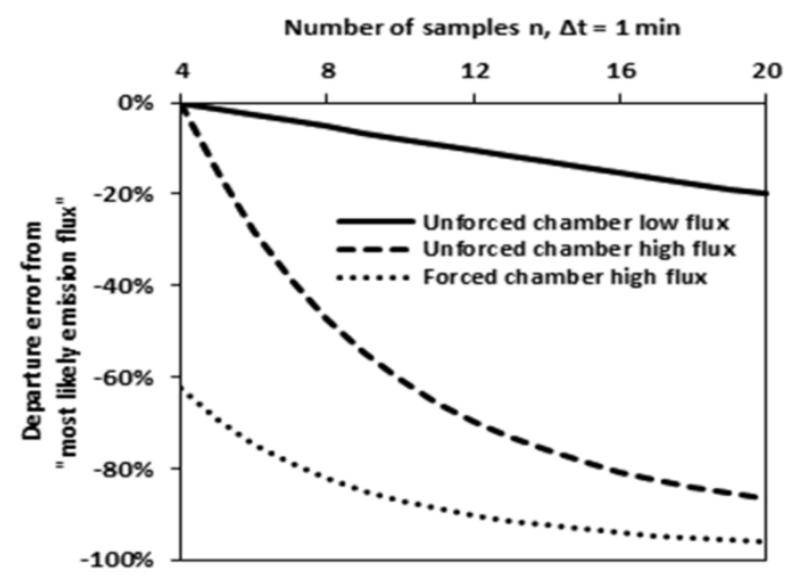

Figure 5. Theoretical linear departure error of chamber models from "real flux" gaseous emission sources

We plotted the number of $\mathrm{n}$ samples in each modeled deployment presented in Figure 4 as a function of the percentage departure (error) from the best linear or "real" flux for $n=4$ (departure error $=0 \%$ ). Despite of the underestimation observed for all modeled fluxes, the unforced low flux model (or analogously high headspace chamber for the same surface area) shows the lowest departure error comparatively to the "real flux" as $\mathrm{n}$ increases. That result is in agreement to Wang et al. (2013), whose suggest chamber fluxes lower than expected when compared to the micrometeorological technique due to failure to detect linearity/nonlinearity in the flux calculation.

\subsection{Implication of the Modeling to Real Data}

The modeling herein discussed was in a great extent derived from the dataset Plot/User experiment (Figure 2). It 
allowed us to verify that, especially for a great source of a specific target gas, both chamber design (headspace volume (Conen, 2000) and chamber handling (placement and sampling rate) can be managed to the measurement be as close as possible from the "most likely flux". This approach is only possible with on-site measuring systems and the best options are continuous monitoring devices that do not interfere in chamber pressure while sampling (Christiansen et al., 2011), and are able to be attached to static and also dynamic chamber designs (Gao et al., 1997; Bergier et al., 2011). However, for trace gases with very small partial pressures in the atmosphere, such as $\mathrm{N}_{2} \mathrm{O}$, a GC/ECD with a high signal-to-noise ratio in the field would be more precise, though restricting the measurements to the closed static chamber approach, and care must be taken to avoid chamber depressurization (Christiansen et al., 2011) and Venturi effects (Conen \& Smith, 1998; Bain et al., 2005).

Applying the general findings to the dataset we can estimate by linear regressions the "best fluxes" for data obtained by User 1 , discarding the last samples $(\mathrm{n}=3)$ because they are likely already at the asymptotic regime. From this, we obtain for Plots 1 and 2 respectively $0.56 \mathrm{mg} \mathrm{N} \mathrm{N}_{2} \mathrm{O} \cdot \mathrm{m}^{-2} \cdot \mathrm{h}^{-1}\left(\mathrm{R}^{2}=1.00\right)$ and $0.66 \mathrm{mg} \mathrm{N} \mathrm{O}_{2} \cdot \mathrm{m}^{-2} \cdot \mathrm{h}^{-1}\left(\mathrm{R}^{2}\right.$ $=0.94$ ). The measurement made by User 1 in plot 3 cannot be estimated through linear regression due to the high amount of the applied $\mathrm{N}$, to the subsequent high soil $\mathrm{N}_{2} \mathrm{O}$ emission, and hence faster chamber saturation in the asymptotic regime.

In order to assess the coherence in the magnitude of the measured fluxes, we constructed a realistic $\mathrm{N}$ budget. Table 3 summarizes information on $\mathrm{N}$ inputs through fertirrigation, nitrification rates estimated by laboratory analysis (Fernandes et al., 2012), $\mathrm{N}_{2} \mathrm{O}$ emissions from User 1 data, the nitrification period required to transform all $\mathrm{N}-\mathrm{NH}_{4}$ inputs to $-\mathrm{N}-\mathrm{NO}_{3}$, and the elapsed time of the measured $\mathrm{N}_{2} \mathrm{O}$ flux after fertirrigation. The $\mathrm{N}$ budget in Table 3 presents reasonable consistency, where the elapsed times for the chamber deployments are suitably below the minimal theoretical time to convert all $\mathrm{N}_{-} \mathrm{NH}_{4}$ to $\mathrm{N}-\mathrm{NO}_{3}$, and for Plots 1 and 2 the hourly $\mathrm{N}-\mathrm{N}_{2} \mathrm{O}$ fluxes is about 3.4 to $3.8 \%$ of the hourly converted $\mathrm{N}^{-\mathrm{NO}_{3}}$. From these proportions, and assuming that a great fraction of the $\mathrm{N}_{2} \mathrm{O}$ emissions at local conditions is derived from denitrification, though possibly concurrently derived from nitrification (Singurindy et al., 2009; Marschner \& Rengel, 2007; Zhang et al., 2011), we can roughly estimate that $\mathrm{N}_{2} \mathrm{O}$ emissions from Plot 3 might be in between 0.502 to $0.560 \mathrm{mg} \mathrm{N}-\mathrm{N}_{2} \mathrm{O} \cdot \mathrm{m}^{-2} \cdot \mathrm{h}^{-1}(1.58$ to $\left.1.76 \mathrm{mg} \mathrm{N} 2 \mathrm{O} \cdot \mathrm{m}^{-2} \cdot \mathrm{h}^{-1}\right)$.

Table 3. Preliminary nitrogen cycling data for swine-agroecosystem integrations

\begin{tabular}{|c|c|c|c|c|c|}
\hline & $\begin{array}{l}\text { Applied } \mathrm{N} \\
\text { through } \\
\text { fertirrigation } \\
\mathrm{mg} \mathrm{N}-\mathrm{NH}_{4} \cdot \mathrm{m}^{-2}\end{array}$ & $\begin{array}{l}\text { Estimated linear } \\
\text { nitrification rate } \\
\mathrm{mg} \mathrm{N}-\mathrm{NO}_{3} \cdot \mathrm{m}^{-2} \cdot \mathrm{h}^{-1}\end{array}$ & $\begin{array}{l}\text { Nitrous oxide } \\
\text { emissions (User 1) } \\
\text { on } 10^{\text {th }} \text { May } 2012 \\
\mathrm{mg} \mathrm{N}-\mathrm{N}_{2} \mathrm{O} \cdot \mathrm{m}^{-2} \cdot \mathrm{h}^{-1}\end{array}$ & $\begin{array}{l}\text { Minimal time to } \\
\text { fully convert } \\
\mathrm{N}-\mathrm{NH}_{4} \text { to } \mathrm{N}-\mathrm{NO}_{3} \\
\text { days }\end{array}$ & $\begin{array}{l}\text { Elapsed time after } \\
\text { fertirrigation for } \\
\text { chamber deployments } \\
\text { days }\end{array}$ \\
\hline Plot 1 & 1794 & 4.731 & 0.179 & 16 & 13 \\
\hline Plot 2 & 2405 & 6.246 & 0.212 & 16 & 12 \\
\hline Plot 3 & 5860 & 14.816 & 0.502 to $0.560^{\mathrm{a}}$ & 17 & 8 \\
\hline
\end{tabular}

${ }^{\text {a }}$ Calculated as 3.4 to $3.8 \%$ of the $\mathrm{N}-\mathrm{NO}_{3}$ input.

Alternatively, a fraction of the $\mathrm{N}_{2} \mathrm{O}$ emissions measured in $10^{\text {th }}$ May 2012 can be also explained by soil fertilization with NPK 10-15-15 (equivalently to $1000 \mathrm{mg} \mathrm{N} \cdot \mathrm{m}^{-2}$ ) while seeding maize in $24^{\text {th }}$ March 2012. Therefore, total $\mathrm{N}$ inputs for Plots 1,2 and 3 might actually be 2794,3405 and $6860 \mathrm{mg} \cdot \mathrm{N} \cdot \mathrm{m}^{-2}$, respectively. Considering the additional N-NPK, the proportion of the estimated $\mathrm{N}-\mathrm{N}_{2} \mathrm{O}$ emissions in relation to the total N inputs might drop to 2.43 to $2.48 \%$, still above the default value of $1 \%$ suggested by IPCC (2006), but within the range of other studies (see Meyer et al., 2006; Table 2 in Zhang et al., 2012). Note that our chamber data is small and was constrained for "most likely flux" estimates (as presented in the modeling section) and we have not removed the crop residue in the top soil. The reason for not cleaning the top soil is that at no-tillage agroecosystems a reasonable fraction of the fertirrigation fertilizer shall be bacterially processed in this organic layer (Assis et al., 2003; Luz, 2007). The important finding we highlight is that there is no standard "magic" chamber design suitable to cover greenhouse gas flux estimates over a broad range of soil (or water) interfaces. More importantly is to understand the behavior of the chamber flux accordingly to chamber design, "most likely instantaneous flux" and user interaction with the chamber. Moreover, linear goodness-of-fit should be critically evaluated as a criterion for accepting linear regressions for chamber fluxes as it can be more exponential than formerly thought (Kutzbach et al., 2007). 


\section{Acknowledgements}

This work was partially funded by MCT/CNPq/Repensa, Grant number 562441/2010-7, and Embrapa/Macroprograma2, Grant number 02.11.05.002. Authors also thank Cooasgo, Retificadora Centro Sul, and Brascarbon for the cooperation in the initiative of the long-term demonstration unit. Ivan Bergier thanks important contributions of two anonymous reviewers.

\section{References}

Assis, E. P. M., Cordeiro, M. A. S., Paulino, H. B., \& Carneiro, M. A. C. (2003). Efeito da aplicação de nitrogênio na atividade microbiana e na decomposição da palhada de sorgo em solo de cerrado sob plantio direto. Pesquisa Agropecuária $\quad$ Tropical, $107-112$. http://www.revistas.ufg.br/index.php/pat/article/view/2362/2339

Bain, W. G., Hutyra, L., Patterson, D. C., Bright, A. V., Daube, B. C., Munger, J. W., \& Wofsy, S. C. (2005). Wind-induced error in the measurement of soil respiration using closed dynamic chambers. Agriultural Forest and Meteorology, 131, 225-232. http://dx.doi.org/10.1016/j.agrformet.2005.06.004

Bergier, I., Goulart, T., Franco, E., Rech, R., Silva, D. S., Oliveira, G. S., ... Ribeiro, T. T. (2012). Fertirrigação e Agricultura de Baixa Emissão de Carbono: Resultados do Projeto CNPq/REPENSA em São Gabriel do Oeste. Embrapa Pantanal: Boletim de Pesquisa, 116, 31. Retrieved from http://www.cpap.embrapa.br/publicacoes/online/BP116.pdf

Bergier, I., Novo, E. M. L. M., Ramos, F. M., Mazzi, E. A., \& Rasera, M. F. F. L. (2011). Carbon dioxide and methane fluxes in the littoral zone of a tropical savanna reservoir (Corumbá, Brazil). Oecologia Australis, 15, 666-681. http://dx.doi.org/10.4257/oeco.2011.1503.17

Burney, J. A., Davisc, S. J., \& Lobella, D. B. (2010). Greenhouse gas mitigation by agricultural intensification. Procedings of the National Academy Sciences, 107, 12052-12057. http://dx.doi.org/10.1073/pnas.0914216107

Chantigny, M. H., Angers, D. A., Rochette, P., Belanger, G., Massé, D. I., \& Côté, D. (2007). Gaseous nitrogen emissions and forage nitrogen uptake on soils fertilized with raw and treated swine manure. Journal of Environmental Quality, 36, 1864-1872. http://dx.doi.org/doi:10.2134/jeq2007.0083

Christiansen, J. R., Korhonen, J. F. J., Juszczak, R., Giebels, M., \& Pihlatie, M. (2011). Assessing the effects of chamber placement, manual sampling and headspace mixing on $\mathrm{CH}_{4}$ fluxes in a laboratory experiment. Plant Soil, 343, 171-185. http://dx.doi.org/10.1007/s11104-010-0701-y

Conen, F., \& Smith, K. A. (1998). A re-examination of closed flux chamber methods for the measurement of trace gas emissions from soils to the atmosphere. European Journal of Soil Science, 701-707. http://dx.doi.org/10.1046/j.1365-2389.1998.4940701.x

Conen, F., \& Smith, K. A. (2000). An explanation of linear increases in gas concentration under closed chambers used to measure gas exchange between soil and the atmosphere. European Journal of Soil Science, 51, 111-117. http://dx.doi.org/10.1046/j.1365-2389.2000.00292.x

Davidson, E. A. (2009). Contribution of manure and fertilizer nitrogen to increasing atmospheric nitrous oxide since 1860. Nature Geosciences, 2, 659-662. http://dx.doi.org/10.1038/ngeo608

Davidson, E. A., Savage, K., Verchot, L. V., \& Navarro, R. (2002). Minimizing artifacts and biases in chamber-based measurements of soil respiration. Agricultural Forest and Meteorology, 113, 21-37. http://dx.doi.org/10.1016/S0168-1923(02)00100-4

Fernandes, A. H. B. M., Cardoso, M. A., Sousa, R. A. C., Fernandes, F. A., Soares, M. T. S., Crispim, S. M. A., \& Lisita, F. (2011). Nitrificação e mineralização de carbono em solos tratados com dejetos de suínos biodigeridos. Boletim de Pesquisa e Desenvolvimento (Centro de Pesquisa Agropecuária do Pantanal), 111, 15. Retrieved from http://www.cpap.embrapa.br/publicacoes/online/BP111.pdf

Forster, P., Ramaswamy, V., Artaxo, P., Berntsen, T., Betts, R., Fahey, D. W., .. Van Dorland, R. (2007). Changes in Atmospheric Constituents and in Radiative Forcing. In S. Solomon, D. Qin, M. Manning, Z. Chen, M. Marquis, K. B. Averyt, M. Tignor, \& H. L. Miller (Eds.), Climate Change 2007: The Physical Science Basis. Contribution of Working Group I to the Fourth Assessment Report of the Intergovernmental Panel on Climate Change. Cambridge: Cambridge University Press. Retrieved from http://www.ipcc.ch/pdf/assessment-report/ar4/wg1/ar4-wg1-chapter2.pdf

Gao, F., Yates, S. R., Yates, M. V., Gan, J., \& Ernst, F. F. (1997). Design, fabrication, and application of a 
dynamic chamber for measuring gas emissions from soil. Environmental Science and Technology, 31, 148-153. http://dx.doi.org/10.1021/es9602511

Hutchinson, G. L., \& Livingston, G. P. (2001). Vents and seals in nonsteady-state chambers used for measuring gas exchange between soil and the atmosphere. European Journal of Soil Science, 52, 675-682. http://dx.doi.org/10.5194/bg-6-2135-2009

IPCC. (2006). 2006 IPCC Guidelines for National Greenhouse Gas Inventories, Volume 4: Agriculture, Forestry and Other Land Use. Retrieved from http://www.ipcc-nggip.iges.or.jp/public/2006gl/pdf/4_Volume4/V4_11_Ch11_N2O\&CO2.pdf

Kutzbach, L., Schneider, J., Sachs, T., Giebels, M., Nykanen, H. Shurpali, N. J., ... Wilmking, M. (2007). CO flux determination by closed-chamber methods can be seriously biased by inappropriate application of linear regression. Biogeosciences, 4, 1005-1025. http://dx.doi.org/10.5194/bg-4-1005-2007

Laville, P., Jambert, C., Cellier, P., \& Delmas, R. (1999). Nitrous oxide fluxes from a fertilised maize crop using micrometeorological and chamber methods. Agricultural and Forest Meteorology, 96, 19-38

Luz, L. P. (2007). Dinâmica do carbono durante a decomposição de palha de trigo marcada com ${ }^{13} \mathrm{C}$ e dejetos líquidos de suínos. M.Sc. Dissertation. Federal University of Santa Maria, Santa Maria, RS. Retrieved from http://w3.ufsm.br/ppgcs/disserta\%E7\%F5es\%20e\%20teses/Disserta\%E7\%E3o\%20Final\%20Laura.pdf

Marschner, P., \& Rengel, Z. (2007). Nutrient cycling in terrestrial ecosystems (p. 397). Berlin, Germany: Springer.

Massé, D. I., Talbot, G., \& Gilbert Y. (2011). On farm biogas production: A method to reduce GHG emissions and develop more sustainable livestock operations. Animal Feed Science and Technology, 166, 436-445. http://dx.doi.org/10.1016/j.anifeedsci.2011.04.075

Meyer, C. P., Kirkby, C. A., Weeks, I., Smith, D. J., Lawson, S., Fattore, A., \& Turner, D. (2006). Nitrous oxide production from irrigated maize cropping in the Murrumbidgee irrigation area: impacts of crop residue management systems. Water to Gold; Proceedings of the Maize Association of Australia 6th Triennial Conference (HumphreysE, O'KeeffeK, HutchingsN \& GillR, Eds.). Maize Association of Australia, Darlington Point, New South Wales (pp. 161-167).

Oenema, O. (2005). Trends in global nitrous oxide emissions from animal production systems. Nutrient Cycling in Agroecosystems, 72, 51-65. http://dx.doi.org/10.1007/s10705-004-7354-2

Rieger, L. O. (2006). Motor estacionário modificado para gás metano (Modified stacionary engine to methane gas). INPI. Brazilian Pending Patent number MU8602925-8, 06/11/2006.

Rochette, P. (2011). Towards a standard non-steady-state chamber methodology for measuring soil $\mathrm{N}_{2} \mathrm{O}$ emissions. Animal Feed Sci. Tech., 166, 141-146. http://dx.doi.org/10.1016/j.anifeedsci.2011.04.063

Singurindy, O., Molodovskaya, M., Richards, B. K., \& Steenhuis, T. S. (2009). Nitrous oxide emission at low temperatures from manure-amended soils under corn (Zea mays L.). Agriculture, Ecosystems and Environment, 132, 74-81.

Sutton, M.A., Oenema, O., Erisman, J.W., Leip, A., Van Grinsven, H., \& Winiwarter, W. (2011). Too much of a good thing. Nature, 472,159-161. http://dx.doi.org/10.1038/472159a

Velthof, G. L., Kuikman, P. J., \& Oenema, O. (2003) Nitrous oxide emissions from animal manure applied to soil under controlled conditions. Biology and Fertiity of Soils, 221-230. http://dx.doi.org/10.1007/s00374-003-0589-2

Wang, K., Zheng, X., Pihlatie, M., Vesala, T., Liu, C., Haapanala, S., ... Liu, H. (2013). Comparison between static chamber and tunable diode laser-based eddy covariance techniques for measuring nitrous oxide fluxes from a cotton field. Agricultural and Forest Meteorology, 171, 9-19.

Zhang, Y., Liu, J., Mu, Y., Xu, Z., Pei, S., Lun, X., \& Cai, F. (2011). Emissions of nitrous oxide, nitrogen oxides and ammonia from a maize field in the North China Plain. Atmospheric Environment, 45, 2956-2961.

Zhang, Y., Liu, J., Mu, Y., Xu, Z., Pei, S., Lun, X., \& Zhang, Y. (2012). Nitrous oxide emissions from a maize field during two consecutive growing seasons in the North China Plain. Journal of Environmental Sciences, 24, 160-168. 


\section{Copyrights}

Copyright for this article is retained by the author(s), with first publication rights granted to the journal.

This is an open-access article distributed under the terms and conditions of the Creative Commons Attribution license (http://creativecommons.org/licenses/by/3.0/). 